\title{
Growth in the limpet Nacella concinna from contrasting sites in Antarctica
}

Received: 18 March 2004/ Revised: 1 June 2004/ Accepted: 4 June 2004 / Published online: 7 August 2004

(C) Springer-Verlag 2004

\begin{abstract}
Annual shell growth was determined by mark and recapture in the limpet Nacella concinna (Strebel 1908) at two contrasting sites in Antarctica. At Signy Island, $60^{\circ} \mathrm{S}$, growth was moderately fast, comparable with some limpets in more temperate areas. The fluorescent calcium marker calcein was used to validate the results from the mark/recapture study, and fine-scale growth increments showed that shell growth was seasonal. Further south at Rothera Point, $67^{\circ} \mathrm{S}$, mean annual growth over a 3-year period was significantly slower than at Signy, and in 1 year was the slowest yet reported for a limpet. Comparison with an earlier mark/ recapture study at Arthur Harbour, Palmer Station $\left(64^{\circ} \mathrm{S}\right)$ revealed a cline of decreasing growth performance with increasing latitude along the Antarctic Peninsula. It is not clear whether the slower annual growth rate at higher latitude was caused by physiological constraints, a reduced length of growing season, or a combination of both. Limpets show a global cline in growth performance, which decreases towards higher latitudes.
\end{abstract}

\section{Introduction}

Knowledge of patterns of growth is fundamental to an understanding of life-history. Annual growth rate is

\footnotetext{
A. Clarke $(\bowtie) \cdot$ E. Prothero-Thomas $\cdot$ J. C. Beaumont

A. L. Chapman

British Antarctic Survey, NERC, High Cross,

Madingley Road, Cambridge, CB3 OET, UK

E-mail: accl@bas.ac.uk

Fax: + 44-1223-221259

J. C. Beaumont

Scottish Association for Marine Science,

Dunstaffnage Marine Laboratory, Oban,

Argyll, PA37 1QA, Scotland

T. Brey

Alfred-Wegener-Institut für Polar- und Meeresforschung,

27568 Bremerhaven, Germany
}

critical to population dynamics, and patterns of seasonal growth rate provide valuable insight into the ecological factors influencing growth. In high-latitude ecosystems, seasonal patterns of growth may also be used to examine evolutionary adaptation to temperature (Clarke 1991).

The Antarctic limpet Nacella concinna (Strebel 1908) (family Nacellidae) is widely distributed in the Southern Ocean, being found from South Georgia, islands of the Scotia arc and along the Antarctic Peninsula (Powell 1973). It is very abundant in shallow waters, with a subpopulation that moves into the intertidal in summer (Walker 1972). These intertidal limpets move back into the subtidal in winter when the ice-foot forms, and can be distinguished morphologically from the non-migratory subtidal population (Walker 1972; Nolan 1991a). They cannot, however, be distinguished genetically using allozymes (Beaumont and Wei 1991).

$N$. concinna has been studied widely in Antarctica (Walker 1972; Shabica 1976; Picken 1980; Brêthes et al. 1994). Although there is a general consensus that annual growth is slow, estimates of growth rate differ between studies. This may reflect geographical or interannual variability in growth, but it may also result from differences in technique. In particular, the technique of following modal size-classes in sequential samples is often very difficult in slow-growing species with intermittent recruitment, both of which are features typical of Antarctic benthic marine invertebrates (Clarke 1983; Brey and Clarke 1993).

An alternative to size-frequency analysis is to section the shell and determine annual growth from bands in the shell structure (Richardson 2001). This technique, although time-consuming, may also provide valuable information on shorter-term patterns of growth (seasonal, daily or even tidal). Unfortunately, this technique has also proved problematical in many polar animals, as the slow overall growth rate produces very narrow growth bands, which can be misinterpreted (Peck and Brey 1996; Peck et al. 1997). In extreme cases, it can even be difficult to establish what 
constitutes an annual set of growth bands. These problems can be alleviated by the use of a permanent internal shell marker, as long as the protocol used can be shown not to affect the growth measurement. Recent studies have suggested that the non-toxic calcium marker calcein may be such a suitable marker (Medeirosbergen and Ebert 1995; Stewart 1996; Moran 2000; Lamare and Mladenov 2000).

It is therefore unlikely that size-frequency analyses will provide robust estimates of growth in Antarctic marine invertebrates, except perhaps in the earliest stages of growth. A better approach is to follow the growth of individual animals in the field using mark and recapture techniques, where individual animals are measured before and after a period of growth in the natural environment. This period must be long enough for measurable growth to take place, and in Antarctica marine invertebrate growth is typically so slow that individuals must be left for quite long periods, typically at least 1 year, in order to obtain measurable growth.

The aims of this study were therefore:

1. To compare the annual shell growth of $N$. concinna at two sites in Antarctica, using mark and recapture techniques, and compare these data with previous studies.

2. To determine seasonal patterns of shell growth in $N$. concinna from internal growth bands, using calcein as an internal shell mark.

\section{Materials and methods}

\section{Mark and recapture experiment at Signy Island}

Samples of $N$. concinna (Strebel 1908) were collected by scuba-divers from depths of 6-8 $\mathrm{m}$ close to the research station at Signy Island (Fig. 1) in early March 1994. A wide size range (12-40 $\mathrm{mm}$ in length) was selected, and care was taken to sample only the subtidal population. Limpets were held in recirculating aquaria maintained at ambient seawater temperature $\left(0 \pm 0.5^{\circ} \mathrm{C}\right)$ whilst they were measured and labelled.

The length and breadth of 227 limpets were measured to the nearest $\pm 0.1 \mathrm{~mm}$ with vernier calipers, and the shell then painted with a unique reference number. For labelling, the limpets were held in shallow trays of seawater to enable them to maintain irrigation of their mantle cavities whilst the top portion of the shell dried. The reference number was applied in enamel paint, and a spot of day-glo paint applied to make subsequent recapture easier. Both marks were sealed with cyanoacrylate gel to reduce loss by abrasion.

Before being returned to the wild, limpets were labelled with calcein, a non-toxic fluorescent marker chemically related to fluorescein and introduced by Diehl and Ellingboe (1956). Calcein binds with calcium at calcification sites in molluscan shells (Stewart 1996), and when excited by blue light $(492-497 \mathrm{~nm})$, it fluo-

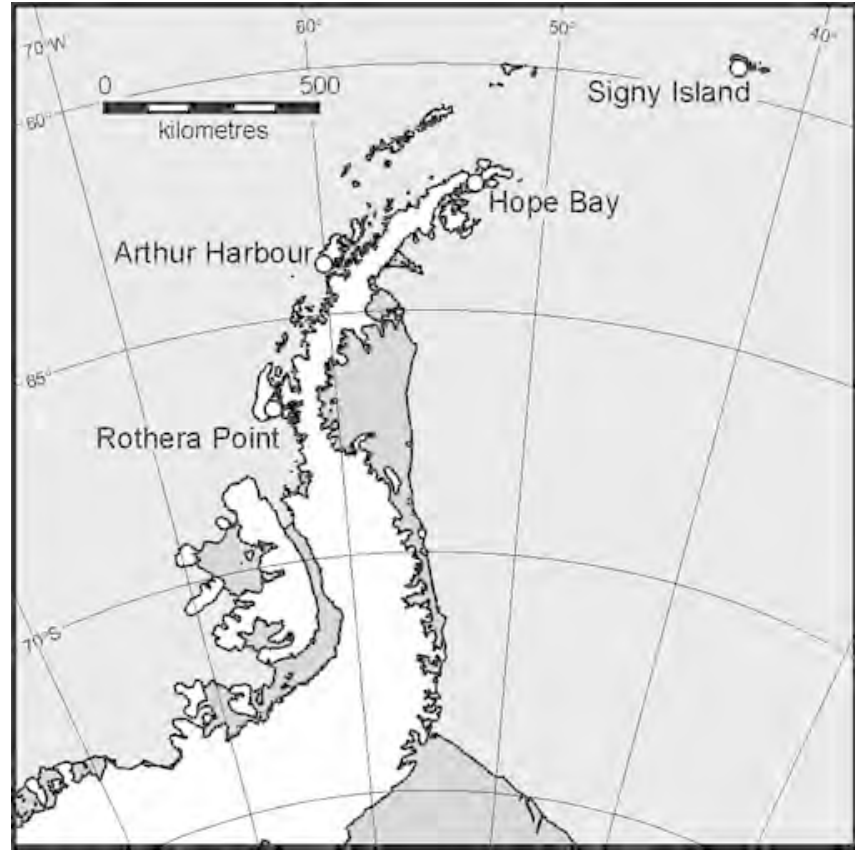

Fig. 1 Map showing location of the sites at which the two measurements of growth in $N$. concinna reported here (Signy Island, Rothera Point) together with the location of the two other sites at which measurements have been made (Arthur Harbour, Hope (Esperanza) Bay)

resces green (519-522 $\mathrm{nm})$ and can be seen clearly in thin sections of the shell. Limpets were marked with calcein by holding them for $72 \mathrm{~h}$ in an aerated tank of seawater at ambient temperature containing $500 \mathrm{mg}^{-1}$ of calcein. The addition of calcein turns seawater slightly acidic and the $\mathrm{pH}$ was adjusted back to $\mathrm{pH} 8.10$ (ambient seawater at Signy Island) using $0.1 \mathrm{~m} \mathrm{NaOH}$. Limpets were then transferred to a tank of clean seawater for $24 \mathrm{~h}$ before being returned to the wild close to the point from which they had been collected initially.

In total, 126 marked limpets were recovered by scuba-divers in late February 1995 (Table 1). Logistic constraints prevented a more thorough recovery of the labelled limpets, and restricted the free-living period to slightly less than a full year. Each limpet was remeasured with vernier calipers, shucked of tissue and the dried shell returned to the United Kingdom.

\section{Thin sections of limpet shells from Signy Island}

For examination of the calcein marker band, a thin sagittal section $(0.1 \mathrm{~mm})$ was cut from the centre of the shell, polished and mounted on a microscope slide. The section was then examined with a compound epifluoresence microscope using a blue filter (470- to $500-\mathrm{nm}$ bandpass) on the excitation light. The calcein band fluoresced bright-green; it was sharply defined, and could be detected easily at either end of the shell. The growth increment could therefore be measured precisely at both ends (front and rear) of the shell section, and 
Table 1 Mark and recapture details for N. concinna at Signy Island, Rothera Point (this study) and Arthur Harbour (Shabica 1976). Duration is the period between returning the limpet to the wild, and subsequent recapture

\begin{tabular}{|c|c|c|c|c|c|}
\hline \multirow[t]{2}{*}{ Site } & \multirow[t]{2}{*}{ Year marked } & \multicolumn{2}{|l|}{ Number } & \multirow{2}{*}{$\begin{array}{l}\text { Duration in days } \\
\text { (mean } \pm \mathrm{SE})\end{array}$} & \multirow{2}{*}{$\begin{array}{l}\text { Length range } \\
\text { marked (mm) }\end{array}$} \\
\hline & & Marked & Recovered (\%) & & \\
\hline Signy Island & 1994 & 227 & $126(55)$ & $330 \pm 1$ & $12-40$ \\
\hline \multirow[t]{3}{*}{ Rothera Point } & 1997 & 455 & $188(40)$ & $378 \pm 1$ & $6-50$ \\
\hline & 1998 & 367 & $120(33)$ & $367 \pm 2$ & $13-43$ \\
\hline & 1999 & 255 & $90(35)$ & $325 \pm 5$ & $14-41$ \\
\hline Arthur Harbour & 1970 & 627 & $192(31)$ & $365^{\mathrm{a}}$ & $5-49$ \\
\hline
\end{tabular}

${ }^{\text {a }}$ Shabica adjusted the length increment data he recorded to correspond to a duration of precisely 365 days.

summing the growth increment on the two sides gave a measure of total growth increment.

The thin sections were also examined with scanning electron microscopy. Fine-scale growth bands were clearly visible and the total number of these bands between the calcein mark and the growing edge of the shell was counted for five shells of differing size.

\section{Mark and recapture experiment at Rothera Point}

A similar mark and recapture experiment was undertaken close to the research station at Rothera Point, Adelaide Island (Fig. 1). Limpets were collected, marked and recaptured in the same way as at Signy, except that the exposure period was from mid-winter to mid-winter, and the limpets were not labelled with calcein. Three consecutive experiments were undertaken. The first ran from July 1997 to 1998, the second from July 1998 to August 1999, and the third from August 1999 to 2000. Details of these experiments are given in Table 1.

\section{Mark and recapture data from Arthur Harbour}

An earlier, unpublished, mark/recapture study of shell growth in $N$. concinna was undertaken at an intermediate latitude (Arthur Harbour, Palmer Station; Fig. 1) by Shabica (1976). In this study, 627 intertidal and subtidal limpets were marked and $194(31 \%)$ recovered between 321 and 358 days later. Shabica adjusted all size increments linearly to a growth period of 365 days. Although the raw data are no longer available, a detailed plot of the corrected growth increment in relation to initial length (Fig. 80 in Shabica 1976) allows a direct comparison with our results.

\section{Statistical analysis of mark/recapture data}

We designate the shell length at first capture by $L_{1}$ at $t_{1}$ (where $t_{1}$ is the time of return to the wild after marking), the corresponding recapture data as $L_{2}$ at $t_{2}$, the length increment by $\mathrm{d} L\left(=L_{2}-L_{1}\right)$ and the time lag by $\mathrm{d} t$ $\left(=t_{2}-t_{1}\right)$. Six limpets whose apparent growth increment was negative and which had decreased in shell length by more than $1 \mathrm{~mm}$ were assumed to represent measurement errors, and hence were excluded from further analysis.
Mark/recapture data were arranged in the form $L_{1}$ at $t_{1}$ and $L_{2}$ at $t_{2}$ to enable a variety of growth models to be fitted to the data sets from the different sites and/or years using an iterative non-linear procedure based on the Newton algorithm. The growth models fitted comprised the specialized von Bertalanffy, generalized von Bertalanffy, Gompertz, Richards and Tanaka models. The fit of all these were similar, so we chose to fit the simplest model, which was the specialized von Bertalanffy:

$$
\begin{aligned}
L_{t} & =L_{\infty} \times\left(1-\mathrm{e}^{-K \times\left(t-t_{0}\right)}\right) \Leftrightarrow L_{2} \\
& =L_{1}+\left(L_{\infty}-L_{1}\right) \times\left(1-\mathrm{e}^{-K \times\left(t_{1}-t_{2}\right)}\right)
\end{aligned}
$$

Overall growth performance was measured by the index, $\varnothing$, of Munro and Pauly (1983). This index was derived empirically from the relationship between $K$ and $L_{\infty}$, observed in many fish stocks, and calculated as:

$\emptyset=\ln (K)+2 \ln \left(L_{\infty}\right)$

Significant differences in growth between sites/years were identified by analysis of covariance (ANCOVA) (increment $\mathrm{d} L$ vs site/year and covariate initial size $L_{1}$ ) and subsequent post-hoc test with Tukey's HSD. Data from limpets of initial length $\left(L_{t}\right)$ outside the range 14 $40 \mathrm{~mm}$ were omitted to avoid any bias caused by sitespecific differences in size spectra. Note that the relation between $\mathrm{d} L$ and $L_{1}$ resembles the linearized form of the von Bertalanffy model introduced by Chapman (1961) and Gulland (1969).

\section{Results}

Validation of growth increment measures by calcein labelling

In total, 126 limpets labelled with calcein at Signy in 1994 were recovered in 1995 and their shells returned to the United Kingdom. A subsample of 40 of these limpets was selected at random, covering the range of annual increments observed, and examined microscopically.

The calcein growth mark was very sharp, and clearly visible by microscopy. The annual increment in shell growth as measured from the calcein mark, and summing data from both sides of the shell, was compared 
with that estimated directly from mark/recapture study of the same limpets (Fig. 2). The correlation between the two measures was highly significant $\left(r^{2}=0.89\right.$, $P<0.001$ ), and the hypothesis that the fitted regression line passed through the origin could not be rejected $(P>0.10)$. The slope of the fitted relationship was, however, significantly less than unity $(b=0.789$, $P<0.05)$. The explanation for the lower slope lies in the geometry of the limpet shell. The annual increment in shell material in a limpet increases both height and length of the shell. Both increments are measured by the calcein labelling and microscopy, whereas mark/recapture measures only the increment in length.

\section{Analysis of fine-scale internal growth marks}

Numerous internal fine-scale growth marks were detected in the five shells from Signy Island examined with a scanning electron microscope. The total number of fine-scale growth marks was far from easy to determine, because individual growth marks varied greatly in their clarity. Data for the total number of growth marks detected between the calcein mark and shell edge for five limpets varying in size are given in Table 2. All of the shells examined showed a cyclic variation in distance between successive fine-scale growth marks, which ranged from 4 to $>16 \mu \mathrm{m}$ (Fig. 3). During the periods shortly after tagging and immediately before recapture (at the end and the start of the austral winter), growth marks were narrowly spaced; in between (presumably during the peak of the austral summer), they were more

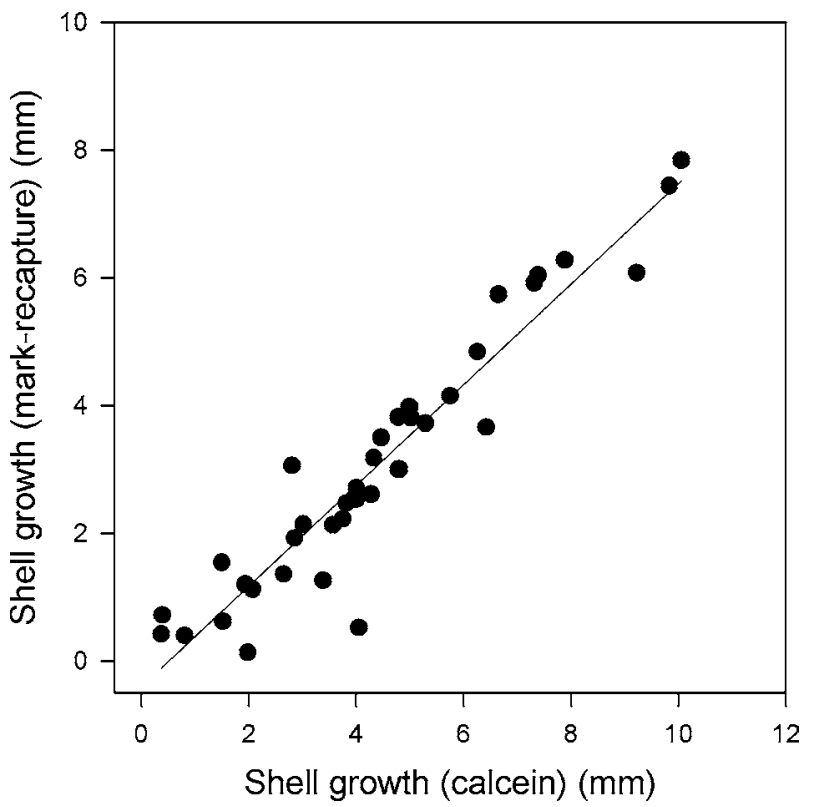

Fig. 2 Relationship between annual increment in shell growth of $N$. concinna as measured by mark/recapture and determined from thin sections of shells labelled with calcein. Each data point refers to two measures made on the same individual limpet. The equation of the fitted regression line (model 1, least squares) is: $y=0.789 x-0.408, n=39$
Table 2 Individual fine-scale internal shell growth marks detected in thin sections of the shell using scanning electron microscopy, between the calcein mark and the growing edge of the shell in five individual N. concinna; Signy Island, 1994/1995. $L$ and $S$ refer to the two sides of the sectioned shell; because of the asymmetric shape of the shell, one side of the section $(L)$ showed a larger absolute annual growth increment than the other $(S)$. Annual growth is the absolute increment in shell length between mark and recapture, and duration is the period between returning the individual limpet to the wild and subsequent recapture

\begin{tabular}{|c|c|c|c|c|c|c|}
\hline \multirow[t]{2}{*}{$\begin{array}{l}\text { Initial } \\
\text { length } \\
(\mathrm{mm})\end{array}$} & \multirow[t]{2}{*}{$\begin{array}{l}\text { Annual } \\
\text { growth } \\
(\mathrm{mm})\end{array}$} & \multirow[t]{2}{*}{$\begin{array}{l}\text { Duration } \\
\text { (days) }\end{array}$} & \multicolumn{2}{|c|}{$\begin{array}{l}\text { Number of } \\
\text { fine-scale } \\
\text { marks }\end{array}$} & \multicolumn{2}{|c|}{$\begin{array}{l}\text { Growth } \\
\text { bands/day }\end{array}$} \\
\hline & & & $L$ & $S$ & $L$ & $S$ \\
\hline 12 & 8 & 330 & 836 & 746 & 2.53 & 2.26 \\
\hline 12 & 6 & 329 & 972 & 797 & 2.95 & 2.42 \\
\hline 24 & 3 & 329 & 413 & 320 & 1.26 & 0.97 \\
\hline 31 & $<1$ & 331 & 200 & 154 & 0.60 & 0.47 \\
\hline 34 & $<1$ & 329 & 302 & 221 & 0.92 & 0.67 \\
\hline
\end{tabular}

widely spaced. These differences in the breadth of finescale internal shell growth bands are typical of molluscs with seasonal shell growth (Richardson 2001).

\section{Limpet growth from mark/recapture data}

The recovery rate of marked limpets ranged between 31 and $55 \%$, and the average time lag between marking and recapture was approximately 1 year at all sites (Table 1). Previous studies of $N$. concinna at Signy Island had

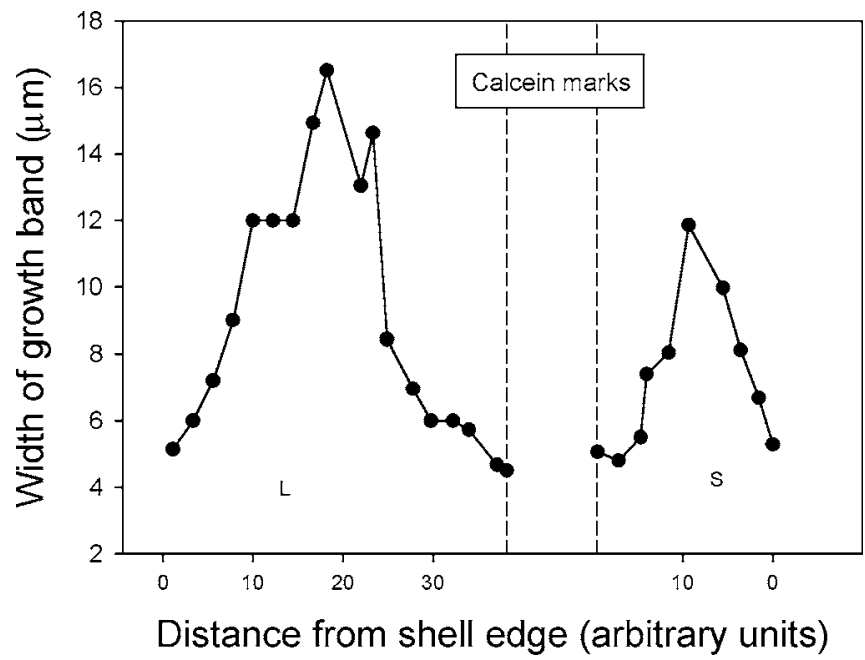

Fig. 3 Variation in the mean size $(\mu \mathrm{m})$ of fine-scale internal shell growth marks, within a period of growth of just under 1 year (late February 1994-early March 1995) in a single individual Antarctic limpet $N$. concinna, at Signy Island. A total of five individuals were examined and all showed a qualitatively similar pattern. $L$ and $S$ refer to the two sides of the sectioned shell; because of the asymmetric position of the shell apex, one side of the sectioned shell $(L)$ showed a larger annual growth increment than the other $(S)$. The initial shell length was $12 \mathrm{~mm}$, and the total annual shell increment $(L+S)$ was $8 \mathrm{~mm}$. The dashed vertical lines indicate the position of the calcein marker band which defines the start of the growth period 
shown that, at least in young individuals, the annual increment in shell growth was confined to the summer and was largely complete by early March (Picken 1980; Nolan 1991b), and a seasonal variation in shell growth was also indicated in our study by the analysis of finescale growth marks in the shell (Fig. 3). The linear adjustment of all growth increments to a standard growth period of 365 days caused negligible change in either growth model parameters or the ANCOVA results. Raw growth increment data (unadjusted for actual value of $\mathrm{d} t$ ) were therefore used in all statistical analyses, although for Arthur Harbour (Shabica 1976), only the corrected data were available.

The annual increment of shell growth in $N$. concinna was highly variable between sites (Fig. 4), as well as between years (Fig. 5). Growth differed significantly $(P<0.05)$ between all data sets except Arthur Harbour (1970) and Rothera Point (1999) (Table 3). As would be expected from the growth increment plots (Figs. 4, 5), the parameters of the von Bertalanffy growth model varied substantially between data sets, as did the corresponding growth performance index $\varnothing$ (Table 2). The growth increment plot (Fig. 5), as well as the Ø-value of 6.065 (Table 3) indicate that annual shell growth was particularly rapid in the season 1998/1999 at Rothera Point.

Not all marked limpets were recovered the following year (Table 1). However, 31 limpets marked at Rothera Point in 1997 were recovered in all subsequent years. Plots of annual growth increment in these limpets
Fig. 4 Annual growth in the Antarctic limpet $N$. concinna at three sites in Antarctica. Data for the three sites are shown separately (black symbols Signy Island, $60^{\circ} \mathrm{S}, 1994 ;$ grey symbols Arthur Harbour, $64^{\circ} \mathrm{S} 1970$, unfilled symbols Rothera Point, 67'S, 1997, 1998 and 1999). Individual regression lines marked to identify site of study (SI Signy Island; $A H$ Arthur Harbour; $R P$ Rothera Point)
Fig. 5 Annual growth in the Antarctic limpet $N$. concinna at Rothera Point. Data for the 3 years of the study are shown separately (black symbols limpets marked in winter 1997 and recovered in 1998, grey symbols limpets recovered or marked fresh in 1998 and recovered in 1999, unfilled symbols limpets recovered or marked fresh in 1999 and recovered in 2000). Individual regression lines are identified by the year of marking
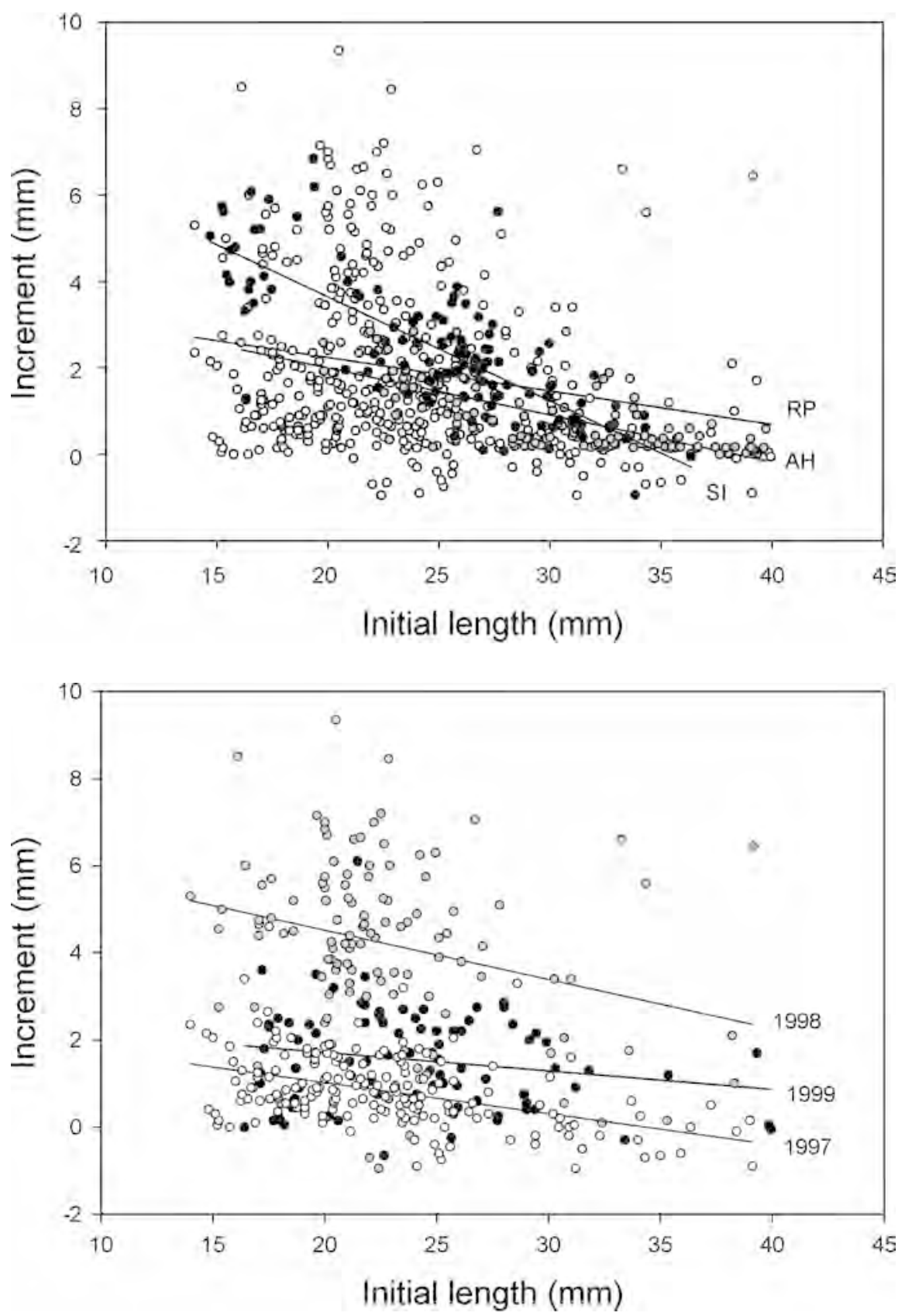
Table 3 Latitudinal and interannual variability in shell growth of the Antarctic limpet $N$. concinna from mark/recapture studies. Data uncorrected for variations from 1 year between mark and recapture, except for data from Arthur Harbour (Shabica 1976) where raw data are no longer available. ANCOVA (increment vs site and initial size) and subsequent Tukey's post-hoc test indicate significant $(P<0.05)$ difference in growth between all sites and years except those marked by *. Von Bertalanffy growth model parameters $L_{\infty}$ and $K$ obtained by iterative non-linear fitting. Growth performance index $\varnothing=\ln (K)+2 \ln \left(L_{\infty}\right)$ (Munro and Pauly 1983)

\begin{tabular}{|c|c|c|c|c|c|c|c|}
\hline Site & Latitude S & Year of marking & $n$ & $L_{\infty}$ & $K$ & $r^{2}$ & $\varnothing$ \\
\hline Signy Island & $60^{\circ} 43^{\prime}$ & 1994 & 125 & 34.42 & 0.323 & 0.948 & 5.947 \\
\hline Arthur Harbour & $64^{\circ} 46^{\prime}$ & $1970^{*}$ & 192 & 40.60 & 0.109 & 0.992 & 5.191 \\
\hline \multirow[t]{3}{*}{ Rothera Point } & $67^{\circ} 34^{\prime}$ & 1997 & 90 & 34.63 & 0.075 & 0.982 & 4.499 \\
\hline & & 1998 & 116 & 61.44 & 0.114 & 0.860 & 6.065 \\
\hline & & $1999 *$ & 186 & 49.74 & 0.073 & 0.974 & 5.196 \\
\hline \multicolumn{3}{|c|}{ Not included in ANCOVA: Rothera Point (pooled data) } & 392 & 50.59 & 0.079 & 0.894 & 5.309 \\
\hline
\end{tabular}

(Fig. 6) showed that the interannual variability in population mean growth rate determined from statistical analysis of the entire data set was exhibited by all individuals, and not just a few. This points clearly to environmental factors forcing growth rate variation in the entire population at a given site.

\section{Discussion}

This study has shown that mark/recapture techniques are a suitable approach for determining population growth rates in limpets. Residual variance differed significantly $(P<0.05)$ between years. Although natural variability in growth rate between individuals will contribute to such interannual differences, this suggests that variations in the care with which limpets are sampled and measured by different workers can affect the precision of the results. Use of the fluorescein-related calcium

Fig. 6a,b Increase in total length of limpets recaptured repeatedly at Rothera Point. a Length of nine individual limpets marked in 1997 and subsequently recaptured in every year of the study, selected to cover a range of initial sizes and growth rates. Data for the other 23 limpets recaptured every year are similar but have been omitted from the plot for clarity of presentation. b Pooled data for all 31 limpets marked in 1997 and subsequently recaptured in every year of the study, plotted as mean \pm 1 standard error for length of all 31 limpets. The range of initial lengths when first sampled in 1997 was $13-39 \mathrm{~mm}$

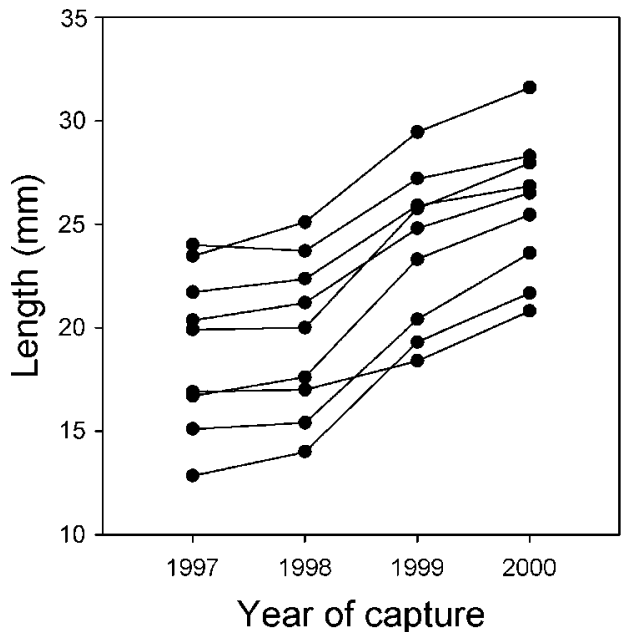

marker calcein verified the mark/recapture data, but analysis of fine-scale internal shell growth marks demonstrated that examination of internal shell structure is likely to be a difficult technique to apply in Antarctic marine invertebrates where growth is both slow and seasonal.

Two features of the shell growth of $N$. concinna are of particular interest. The first is the latitudinal cline in annual growth rate, and the second is comparison with data for other patellacean limpets.

\section{Latitudinal variation in growth rate}

The results from large-scale mark/recapture studies at three sites along the Antarctic Peninsula between $60^{\circ} 43^{\prime}$ (Signy Island) and $67^{\circ} 34^{\prime}$ (Rothera Point) reveal a latitudinal cline in annual shell growth rate which, however, can be obscured by strong interannual variability (Table 3). On average, growth performance was highest at Signy Island $(\varnothing=5.947)$ and equally low at Arthur Harbour (1 year only) and Rothera Point (average of 3 years). During the period 1998/1999, however, growth performance at Rothera $(\varnothing=6.065)$ was even higher than at Signy in 1994/1995, whereas for limpets measured at Rothera the previous year, 1997, growth performance was about $25 \%$ lower. In terms of annual shell growth increments, these differences can be quite large

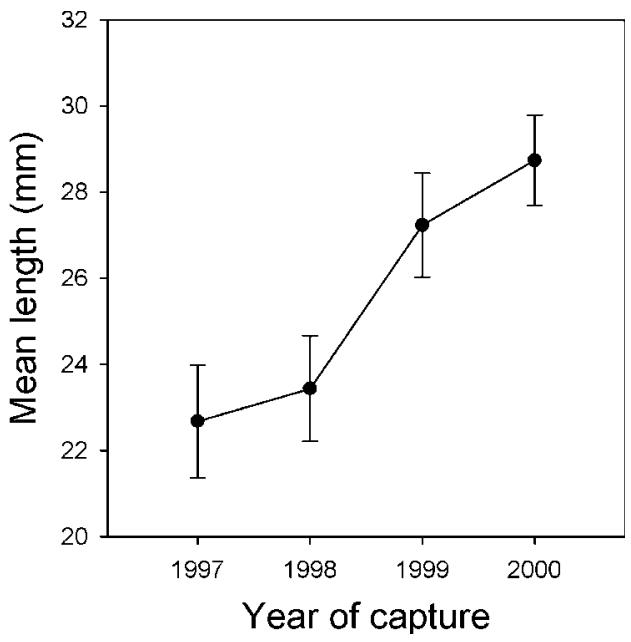


(Figs. 4, 5). Thus for a limpet approaching sexual maturity, which in $N$. concinna is achieved typically at a shell length of $\sim 20 \mathrm{~mm}$ (Picken 1980), growth rates at Signy Island and Rothera Point can differ by a factor of over 3.

Variation in annual growth rate could be the result of a change in the length of the summer growth period (with growth rate unchanged), or a change in growth rate (with growth period unchanged) (Clarke 1991). These two are, however, the extreme possibilities and a more likely explanation is a simultaneous change in both summer growth rate and the duration of the growth period. Like all grazing herbivores, $N$. concinna is dependent upon the seasonal blooming of epiphytic microalgal and microbial biomass, and it is likely that the period of summer production will be shorter at higher latitudes (although we currently have no data to confirm this). Growth rate in marine invertebrates will be influenced by both temperature and food availability. At Rothera Point, limpets marked in 1998 grew significantly faster than those marked in either 1997 or 1999 (Table 3, Fig. 6). Seawater temperatures at Rothera were distinctly warmer in the 1998/1999 summer than in the previous or subsequent summers, in terms of the maximum temperature reached, the length of time for which temperature exceeded an arbitrary threshold of $-1.0^{\circ} \mathrm{C}$, and the integrated degree-days above this threshold (unpublished BAS data for seawater temperature at $15 \mathrm{~m}$ depth). This would suggest that the physical factors affecting growth were more favourable in the 1998/1999 austral summer when Nacella exhibited its fastest recorded growth rate at Rothera Point. Studies of the bryozoan Cellarinella watersi at Signy Island have shown that interannual variation in growth rate is also related to the length of the summer feeding period (Barnes 1995). Unfortunately, we do not have data on the availability of food for Nacella at Rothera Point. Recent work on growth in encrusting intertidal fauna along the Antarctic Peninsula has also shown that growth rate can increase towards higher latitude as a life-history response to disturbance by ice (Barnes and Arnold 1999, 2001).

The confounding influences of growth period and growth rate on annual growth mean that it is very difficult to demonstrate a latitudinal (or other geographical) variation in potential maximum growth rate and hence we cannot come to any conclusions as to whether or not Nacella shows local evolutionary adaptation in growth potential. No studies have yet been undertaken in Antarctica that seek to disentangle the confounding influences of covariation in temperature and food availability; indeed few have been undertaken anywhere. A notable exception has been a series of studies of growth in the Atlantic silverside, Menidia menidia, along the eastern seaboard of the United States. These have shown a high degree of compensation for mean environmental temperature in growth rate, which has been shown by controlled experimentation and breeding experiments to be determined genetically (Conover and
Present 1990; Present and Conover 1992). Studies of embryonic growth in gastropods have also indicated an evolutionary adjustment to intrinsic growth rate at different latitudes (Dehnel 1955; Ament 1979).

Although large-scale comparisons of annual growth rate in Southern Ocean marine invertebrates and fish have shown that higher-latitude species tend to grow more slowly than lower-latitude species (Brey and Clarke 1993; Kock and Everson 1998), these studies do not disentangle the effects of growth rate and growth season. Comparative seasonal studies of feeding and energetics are needed to distinguish whether $N$. concinna shows a latitudinal cline in maximum growth rate. Data from South Georgia would be particularly useful in this respect.

Comparison with other studies of annual growth rate in N. concinna

There have been three other studies of annual growth rate in N. concinna; two from Signy Island (Picken 1980; Nolan 1991b) and one from Hope Bay at the northern end of the Antarctic Peninsula (Brêthes et al. 1994).

Nolan (1991b) undertook a mark/recapture study of 603 intertidal and subtidal limpets, of which 72 littoral and 44 sublittoral individuals were recovered after an average of 198 days (range 33-514) at liberty. Marked shell abrasion was noted in a significant number of individuals (roughly $30 \%$ ). Nine individuals of initial length between 18 and $39 \mathrm{~mm}$ and release periods of between 147 and 363 days were used to estimate the van Bertalanffy growth parameters from a Ford-Walford plot. This very small data set suggested a much lower growth performance than the larger study reported here $(\varnothing=4.345)$, but the result must be treated with some caution because of the small and selective nature of the data set used.

A similarly slow growth rate was reported by Picken (1980). This study utilized the dark bands visible in the shells of $N$. concinna, which monthly samples had indicated were laid down seasonally: limpets collected in summer tended to have a light edge to the shell whereas those collected in winter tended to have a dark edge. Shells could be found with up to five clearly discernible dark bands, though in larger shells the earlier bands were generally indistinct, having been abraded. Measurement of the mean size of these bands in an overlapping series of shells allowed the construction of a Ford-Walford plot for the first 10 years of life. This also suggested a fairly low growth performance $(\varnothing=5.303)$, with a limpet of shell length $15 \mathrm{~mm}$ being 5 years old and growing $2.6 \mathrm{~mm}$ in the following year. Shabica (1976) also used external shell marks to age shells, though he estimated a $15-\mathrm{mm}$ limpet as only $2-3$ years old.

There is thus a striking discrepancy between the very slow growth reported for younger limpets by Picken (1980), and the faster rates for intermediate-sized limpets detected in our study by mark/recapture techniques. The 
generally slow growth typical of polar marine invertebrates (Brey and Clarke 1993) means that it is rarely possible to use techniques involving length/frequency analysis to follow the growth of individual cohorts or year classes through sequential samples. The only exceptions arise when recruitment is constrained to a relatively short time interval and the growth of the youngest cohort can be tracked through time. Both Picken (1980) at Signy Island and Brêthes et al. (1994) at Hope Bay were able to do this, and these studies agree in two respects: the growth of the newly recruited limpets is slow, and it is also seasonal. This newly settled juvenile cohort could clearly be identified as a discrete peak in the monthly size/frequency plots, and growth could also be tracked over the 1st year of post-metamorphic benthic existence.

Picken (1980) first detected newly recruited juveniles in the middle of the austral winter (July), and these individuals had a mean shell length of $0.85 \mathrm{~mm}$. Growth was very slow until early spring, and fastest between November and February, after which period growth effectively ceased. By March, the mean size had doubled to $1.64 \mathrm{~mm}$. A similar pattern was observed at Hope (Esperanza) Bay (Brêthes et al. 1994). Although a few small juveniles could be found at 5 and $10 \mathrm{~m}$ depth from February to June, there was a marked recruitment of juveniles to the sampled population in July. These recruits were, however, larger than those found at Signy Island (the mean size at Hope Bay was $7 \mathrm{~mm}$ ), suggesting that the sampling technique had missed the very small individuals collected at Signy by Picken (1980). The range of sizes collected at Hope Bay was 2-46 mm, and Brêthes et al. (1994) concluded that initial settlement was at depths below those sampled, and they assigned an age of $<1$ year to the 5-mm limpets that first appeared on their samples in July. Given that the newly recruited juveniles whose growth was tracked at Signy had only reached a mean size of $1.64 \mathrm{~mm}$ after their first summer, the smallest limpets observed at Hope Bay may actually have been in their 3rd (rather than 2nd) year. The growth of larger limpets is almost impossible to track through length/frequency histograms, but Brêthes et al. (1994) were able to fit a seasonally varying van Bertalanffy growth curve to estimated modal lengths. This suggested slow growth, and gave an age of 4 years for a limpet of shell length $20 \mathrm{~mm}$.

Growth rates estimated for small limpets $(<10 \mathrm{~mm})$ from length/frequency histograms are thus slow, whereas actual growth determined from mark/recapture of larger limpets (12-40 mm: Table 2, Appendix) is much faster. This suggests that the overall growth curve for $N$. concinna is sigmoidal, with a strong within-year seasonality superimposed.

\section{Comparison with other limpets}

Growth rate has been measured in many species of limpets, and a valuable compilation of data for 20 species is provided by Branch (1981). Values of the von Bertalanffy growth coefficient, $K$, varied from $<0.1$ (Notacmaea petterdi) to 5 (Notacmaea insessa). The data reported here for Nacella concinna (ranging from 0.073 to 0.323 : Table 3), fall in the lower (slowest growing) third of the range reported for all limpets. Comparisons based simply on the von Bertalanffy growth parameter $K$ can, however, be misleading because of the influence of maximum size, $L_{\infty}$, on $K$. We therefore calculated the growth performance index $\varnothing$ for all studies of patellacean limpets known to us where reasonably robust estimates of $K$ and $L_{\infty}$ were available or could be derived from published data. These data reveal a statistically highly significant $(P<0.001)$ inverse relationship between growth performance index and latitude (Fig. 7). N. concinna has the lowest growth performance index reported for any patellacean limpet so far, but is not distinct from the global trend. Since latitude is simply a geographical convention, these data pose the question of what ecological factors that covary with latitude are driving this global pattern in limpet growth performance.

The most obvious environmental factors that might be considered to influence growth rate, and which covary with latitude, are temperature, insolation and photoperiod. Temperature has long been considered to be a major factor regulating growth rate, though careful comparative studies have often revealed significant evolutionary compensation (Conover and Present 1990; Present and Conovor 1992; see also discussion in Clarke 2003). Detailed studies of grazing in several species of Patella have shown that food consumption has a complex relationship with insolation and temperature (Thompson et al. 2000). For intertidal organisms, temporal patterns of feeding, and hence realized growth

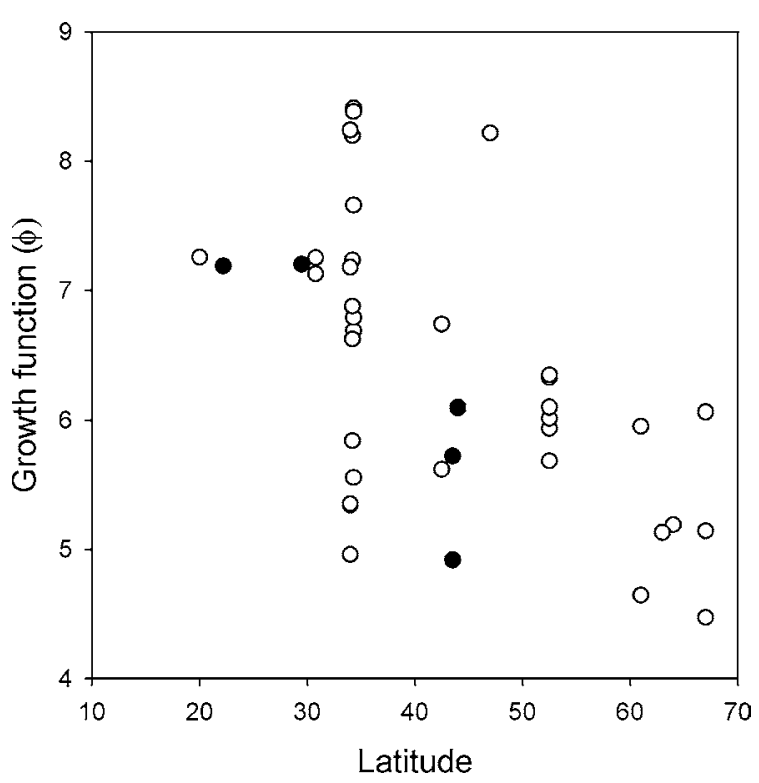

Fig. 7 Growth performance index as a function of latitude in patellacean limpets. Northern hemisphere data are in black and southern hemisphere data are in unfilled circles. Growth performance declines significantly with latitude $(F=18.9, P \leq 0.001)$. Data are listed in Appendix 
rate, will also be affected by factors such as desiccation and predation. That growth rate is regulated by a complex suite of factors is shown clearly by the wide range of growth rates exhibited at any given latitude (Fig. 7). Nevertheless, it is also clear that at the macroecological scale there exists a broad relationship between realized growth rate and latitude. The challenge is to determine the underlying causes.

\section{Conclusion}

The growth of the Antarctic limpet Nacella concinna is seasonal, with shell being produced predominantly in summer. Annual shell growth is generally slow, with the rate at Rothera Point $\left(67^{\circ} \mathrm{S}\right)$ being the slowest yet recorded for any limpet. Annual growth varies

Growth performance data for patellacean limpets. Data arranged by latitude to ease comparison with Fig. 7 (negative latitudes are southern hemisphere). In some cases values of $K$ and $L_{\infty}$ are provided in the original literature cited; in others $(*)$ these have been derived from data or plots in the paper. These studies involve a

\begin{tabular}{|c|c|c|c|c|c|c|}
\hline Species & Latitude & $K$ & $L_{\infty}$ & $\varnothing$ & Location & Reference \\
\hline Nacella concinna & -67.0 & 0.059 & 38.5 & 4.47 & Rothera Point (1997/8) & This paper \\
\hline N. concinna & -67.0 & 0.129 & 57.6 & 6.06 & Rothera Point (1998/9) & This paper \\
\hline N. concinna & -67.0 & 0.068 & 50.2 & 5.14 & Rothera Point (1999/2000) & This paper \\
\hline N. concinna & -64.0 & 0.109 & 40.6 & 5.19 & Palmer Station & Shabica (1976) \\
\hline N. concinna & -63.0 & 0.080 & 46.0 & 5.13 & Hope Bay & Brêthes et al. (1994) \\
\hline N. concinna & -61.0 & 0.323 & 34.5 & 5.95 & Signy Island & This paper \\
\hline$N$. concinna & -61.0 & 0.062 & 41.0 & 4.65 & Signy Island & Picken 1980 \\
\hline Nacella magellanica & -52.5 & $0.191^{*}$ & $54.0 *$ & 6.32 & Straits of Magellan & Gunzman and Rios (1987) \\
\hline N. magellanica & -52.5 & $0.147 *$ & $55.0^{*}$ & 6.10 & Straits of Magellan & Gunzman and Rios (1987) \\
\hline N. magellanica & -52.5 & $0.127 *$ & $67.0^{*}$ & 6.35 & Straits of Magellan & Gunzman and Rios (1987) \\
\hline N. magellanica & -52.5 & $0.110^{*}$ & $61.0^{*}$ & 6.01 & Straits of Magellan & Gunzman and Rios (1987) \\
\hline N. magellanica & -52.5 & $0.079 *$ & $61.0^{*}$ & 5.69 & Straits of Magellan & Gunzman and Rios (1987) \\
\hline N. magellanica & -52.5 & $0.026^{*}$ & $120.0 *$ & 5.94 & Straits of Magellan & Gunzman and Rios (1987) \\
\hline$N$. delesserti & -47.0 & 0.971 & 61.8 & 8.22 & Marion Island & Blankley and Branch (1985) \\
\hline Cellana ornata & -42.5 & 0.536 & 39.7 & 6.74 & First Bay; Kaikura, NZ & Dunmore and Schiel (2003) \\
\hline C. ornata & -42.5 & 0.400 & 26.3 & 5.62 & Blue Duck; Kaikura, NZ & Dunmore and Schiel (2003) \\
\hline Scutellastra cochlear & -34.3 & 0.334 & 49.0 & 6.69 & Kommetjie, South Africa & Branch (1974) \\
\hline S. cochlear & -34.3 & 0.117 & 47.0 & 5.56 & Kommetjie, South Africa & Branch (1974) \\
\hline Cymbula granatina & -34.3 & 0.509 & 94.0 & 8.41 & Kommetjie, South Africa & Branch (1974) \\
\hline Scutellastra granularis & -34.3 & 0.556 & 40.0 & 6.79 & Kommetjie, South Africa & Branch (1974) \\
\hline S. granularis & -34.3 & 0.754 & 53.0 & 7.66 & Elands Bay, South Africa & Branch (1974) \\
\hline Cymbula oculus & -34.3 & 1.020 & 65.5 & 8.38 & Dwesa, South Africa & Branch and Odendaal (2003) \\
\hline S. cochlear & -34.2 & 0.209 & 60.0 & 6.62 & Kalk Bay, South Africa & Branch (1974) \\
\hline S. cochlear & -34.2 & 0.137 & 50.0 & 5.84 & Kalk Bay, South Africa & Branch (1974) \\
\hline S. granularis & -34.2 & 0.671 & 38.0 & 6.88 & Kalk Bay, South Africa & Branch (1974) \\
\hline Scutellastra longicosta & -34.2 & 0.300 & 68.0 & 7.23 & Kalk Bay, South Africa & Branch (1974) \\
\hline C. oculus & -34.2 & 0.582 & 79.0 & 8.20 & Kalk Bay, South Africa & Branch (1974) \\
\hline Cellana tramoserica & -34.0 & $0.832 *$ & $39.7 *$ & 7.18 & Cape Banks, Botany Bay, NSW & Fletcher (1984) \\
\hline C. tramoserica & -34.0 & $1.661^{*}$ & $47.8^{*}$ & 8.24 & Cape Banks, Botany Bay, NSW & Fletcher (1984) \\
\hline Patelloida latistrigata & -34.0 & $1.232^{*}$ & $13.0^{*}$ & 5.34 & Botany Bay, NSW & Creese (1981) \\
\hline Patelloida alticostata & -34.0 & $0.226^{*}$ & $30.5^{*}$ & 5.35 & Botany Bay, NSW & Creese (1981) \\
\hline Notacmaea petterdi & -34.0 & $0.255^{*}$ & $23.7^{*}$ & 4.96 & Botany Bay, NSW & Creese 1981 \\
\hline Cymbola granatina & -30.8 & 0.270 & 67.9 & 7.13 & Groenrivier, South Africa & Branch (1974) \\
\hline Scutellastra argenvillei & -30.8 & 0.210 & 82.0 & 7.25 & Groenrivier, South Africa & Eekhout et al. (1992) \\
\hline Fissurella crassa & -20.0 & $0.159 *$ & $94.5^{*}$ & 7.26 & Huayquique, Chile & Bretos (1980) \\
\hline Cellana grata & 22.2 & $1.014 *$ & $36.2^{*}$ & 7.19 & Cape d'Aguilar, Hong Kong & Liu (1994) \\
\hline Cellana eucosmia & 29.5 & $0.689^{*}$ & $44.1 *$ & 7.20 & Gulf of Suez & Saad (1997) \\
\hline Acmaea digitalis & 43.5 & $0.530^{*}$ & $24.0 *$ & 5.72 & Coos Bay, Oregon & Frank (1965) \\
\hline Acmaea paradigitalis & 43.5 & 0.791 & 13.2 & 4.92 & Coos Bay, Oregon & Frank (1965) \\
\hline Acmaea persona & 44.0 & $0.256^{*}$ & $41.6^{*}$ & 6.09 & Newport, Oregon & Kenny (1968) \\
\hline A. digitalis & ND & 0.583 & 25.8 & 5.96 & California & Choat and Black (1979) \\
\hline A. digitalis & ND & 0.624 & 20.4 & 5.56 & California & Choat and Black (1979) \\
\hline
\end{tabular}

latitudinally, with limpets at Signy Island $\left(60^{\circ} \mathrm{S}\right)$ growing at rates comparable with many temperate limpets. Patellacean limpets show a global cline in growth performance, with annual shell growth being inversely related to latitude.

Acknowledgements Mark/recapture work on free-living marine animals is very labour intensive. We thank all those base members at Signy (1994-1995) and Rothera (1997-2000) for help with diving, but especially Simon Brockington, Keiron Fraser, Rob Wood, Hugh Brown, Lesley Thomson and Craig Barnes. We also thank Ken Robinson for the electron microscopy, Inigo Everson for helpful advice on the estimation of growth rates from field data and George Branch for provision of limpet growth data.

\section{Appendix}

wide range of techniques and sample numbers, and not all studies were concerned primarily with the determination of growth rate; the data must therefore be regarded as indicative rather than definitive in many cases 


\section{References}

Ament AS (1979) Geographical variation in relation to life history in three species of the marine gastropod genus Crepidula: growth rates of newly hatched larvae and juveniles. In: Stancyk SC (ed) Reproductive ecology of marine invertebrates. University of South Carolina Press, Columbia, pp 61-76

Barnes DKA (1995) Seasonal and annual growth in erect species of Antarctic bryozoans. J Exp Mar Biol Ecol 188:181-198

Barnes DKA, Arnold RJ (1999) Possible latitudinal clines in Antarctic intertidal and subtidal zone communities encrusting ephemeral hard substrata. J Biogeogr 26:207-213

Barnes DKA, Arnold R (2001) Competition, sub-lethal mortality and diversity on Southern Ocean coastal rock communities. Polar Biol 24:447-454

Beaumont AR, Wei JHC (1991) Morphological and genetic variation in the Antarctic limpet Nacella concinna (Strebel, 1908). J Mollusc Stud 57:443-450

Blankley WO, Branch GM (1985) Ecology of the limpet $N$. delesserti (Philippi) at Marion Island in the Sub-antarctic Southern Ocean. J Exp Mar Biol Ecol 92:259-281

Brêthes J-C, Ferreyra G, de la Vega S (1994) Distribution, growth and reproduction of the limpet Nacella (Patinigera) concinna (Strebel 1908) in relation to potential food availability in Esperanza Bay (Antarctic Peninsula). Polar Biol 14:161-170

Branch GM (1974) The ecology of Patella Linnaeus from the Cape Peninsula, South Africa. 3. Growth rates. Trans R Soc S Afr 41:161-193

Branch GM (1981) The biology of limpets: physical factors, energy flow and ecological interactions. Oceanogr Mar Biol Annu Rev 19:235-380

Branch GM, Odendaal F (2003) Marine protected areas and wave action: impacts on a South African limpet, Cymbula oculus. Biol Conserv 114:255-269

Bretos M (1980) Age determination in the keyhole limpet Fissurella crassa Lamarck (Archaeogastropoda, Fissurellidae), based on shell growth rings. Biol Bull 159:606-612

Brey T, Clarke A (1993) Population dynamics of benthic marine invertebrates in Antarctic and Subantarctic environments: are there unique adaptations? Antarct Sci 5:253-266

Chapman DG (1961) Statistical problems in dynamics of exploited fisheries populations. Proceedings of the 4th Berkeley symposium on mathematical statistics and probability. Univ Calif Publ Statist 4:153-168

Choat JH, Black R (1979) Life histories of limpets and the limpetlaminarian relationship. J Exp Mar Biol Ecol 41:25-50

Clarke A (1983) Life in cold water: the physiological ecology of polar marine ectotherms. Oceanogr Mar Biol Annu Rev $21: 341-453$

Clarke A (1991) What is cold adaptation and how should we measure it? Am Zool 31:81-92

Clarke A (2003) Costs and consequences of evolutionary temperature adaptation. Trends Ecol Evol 18:573-581

Conover DO, Present TMC (1990) Countergradient variation in growth rate: compensation of length of the growing season among Atlantic silversides from different latitudes. Oecologia 83:316-324

Creese RG (1981) Patterns of growth, longevity and recruitment of intertidal limpets in New South Wales. J Exp Mar Biol Ecol $51: 145-171$

Dehnel PA (1955) Rates of growth of gastropods as a function of latitude. Physiol Zool 28:115-144

Diehl H, Ellingboe JL (1956) Indicator for titration of calcium in the presence of magnesium using disodium dihydrogen ethylenediamine tetracetate. Anal Chem 28:882-884

Dunmore RA, Schiel DR (2003) Demography, competitive interactions and grazing effects of intertidal limpets in southern New Zealand. J Exp Mar Biol Ecol 288:17-38

Eekhout S, Raubenheimer CM, Branch GM, Bosman AL, Bergh MO (1992) A holistic approach to the exploitation of intertidal stocks: limpets as a case history. S Afr J Mar Sci 12:1017-1029
Fletcher WJ (1984) Intraspecific variation in the population dynamics and growth of the limpet, Cellana tramoserica. Oecologia 63:110-121

Frank PW (1965) Growth of three species of Acmaea. Veliger 7:201-202

Gulland JA (1969) Manual of methods for fish stock assessment Part 1. Fish population analysis. FAO Man Fish Sci 4:1-154

Guzman LF, Rios CF (1987) Age and growth of the Subantarctic limpet Nacella (Patinigera) magellanica magellanica (Gmelin, 1791) from the Strait of Magellan, Chile. Veliger 30:159-166

Kenny R (1968) Growth characteristics of Acmaea persona Eschscholtz. Veliger 11:336-339

Kock K-H, Everson I (1998) Age, growth and maximum size of Antarctic notothenioid fish-revisited. In: di Prisco G, Pisano E, Clarke A (eds) Fishes of Antarctica: a biological overview. Springer, Berlin Heidelberg New York, pp 29-40

Lamare MD, Mladenov PV (2000) Modelling somatic growth in the sea urchin Evechinus chloroticus (Echinoidea: Echinometridae). J Exp Mar Biol Ecol 243:17-43

Liu JH (1994) The ecology of the Hong Kong limpets Cellana grata (Gould, 1859) and Patelloida pygmaea (Dunker, 1860): distribution and population dynamics. J Mollusc Stud 60:55-67

Medeirosbergen DE, Ebert TA (1995) Growth, fecundity and mortality rates of two intertidal brittlestars (Echinodermata, Ophiuroidea) with contrasting modes of development. J Exp Mar Biol Ecol 189:47-64

Moran AL (2000) Calcein as a marker in experimental studies newly-hatched gastropods. Mar Biol 137:893-898

Munro JL, Pauly D (1983) A simple method for comparing the growth of fishes and invertebrates. Fishbyte 1:5-6

Nolan CP (1991a) Size, shape and shell morphology in the Antarctic limpet Nacella concinna at Signy Island, South Orkney Islands. J Mollusc Stud 57:225-238

Nolan CP (1991b) Environmental aspects of growth in the Antarctic molluscs Nacella concinna (Patellidae) and Yoldia eightsi (Nuculanidae) at Signy Island, South Orkney Islands. PhD Thesis, University of Hull

Peck LS, Brey T (1996) Bomb signals in old Antarctic brachiopods. Nature 380:207-208

Peck LS, Brockington S, Brey T (1997) Growth and metabolism in the Antarctic brachiopod Liothyrella uva. Philos Trans R Soc Lond Ser B 352:851-858

Picken GB (1980) The distribution, growth and reproduction of the Antarctic limpet Nacella (Patinigera) concinna (Strebel 1908). J Exp Mar Biol Ecol 42:71-85

Powell AWB (1973) The patellid limpets of the world. Indo-Pac Mollusca 3:75-206

Present TMC, Conover DO (1992) Physiological basis of latitudinal growth differences in Menidia menidia: variation in consumption or efficiency? Funct Ecol 6:23-31

Richardson CA (2001) Molluscs as archives of environmental change. Oceanogr Mar Biol Annu Rev 39:103-164

Saad A (1997) Age, growth and morphometry of the limpet Cellana eucosmia (Mollusca: Gastropoda) from the Gulf of Suez. Indian J Mar Sci 26:169-172

Shabica SV (1976) The natural history of the Antarctic limpet Patinigera polaris (Hombron and Jacquinot). $\mathrm{PhD}$ Thesis, Oregon State University

Stewart B (1996) Growth dynamics of the radial shields of the euryalid snake star Astrobrachion constrictum (Echinodermata: Ophiuroidea). Invertebr Biol 115:321-330

Thompson RC, Roberts MF, Norton TA, Hawkins SJ (2000) Feast or famine for intertidal grazing molluscs: a mis-match between seasonal variations in grazing intensity and the abundance of microbial resources. Hydrobiologia 440:357-367

Walker AJM (1972) Introduction to the ecology of the Antarctic limpet Patinigera polaris (Omron and Jacquinot) at Signy Island, South Orkney Islands. Br Antarct Surv Bull 28:49-71

Wei JHC (1988) Morphological and genetic variation in natural populations of Antarctic limpet Nacella concinna. MSc Thesis, University of Wales 